\title{
Purification and identification of metabolites produced by Bacillus cereus and B. subtilis active against Meloidogyne exigua, and their in silico interaction with a putative phosphoribosyltransferase from M. incognita
}

\author{
DENILSON F. OLIVEIRA ${ }^{1}$, HELVÉCIO M. DOS SANTOS JÚNIOR ${ }^{1}$, ALEXANDRO S. NUNES ${ }^{1}$, \\ VICENTE P. CAMPOS ${ }^{2}$, RENATA S.C. DE PINHO ${ }^{2}$ and GIOVANNA C. GAJO ${ }^{1}$ \\ ${ }^{1}$ Universidade Federal de Lavras, Departamento de Química, Caixa Postal, 3037, 37200-000 Lavras, MG, Brasil \\ ${ }^{2}$ Universidade Federal de Lavras, Departamento de Fitopatologia, Caixa Postal 3037, 37200-000 Lavras, MG, Brasil
}

Manuscript received on August 16, 2012; accepted for publication on May 20, 2013

\begin{abstract}
To contribute to the development of products to control Meloidogyne exigua, the bacteria Bacillus cereus and $B$. subtilis were cultivated in liquid medium to produce metabolites active against this plant-parasitic nematode. Fractionation of the crude dichloromethane extracts obtained from the cultures afforded uracil, $9 H$-purine and dihydrouracil. All compounds were active against $M$. exigua, the latter being the most efficient. This substance presented a $\mathrm{LC}_{50}$ of $204 \mu \mathrm{g} / \mathrm{mL}$ against the nematode, while a $\mathrm{LC}_{50}$ of $260 \mu \mathrm{g} / \mathrm{mL}$ was observed for the commercial nematicide carbofuran. A search for protein-ligand complexes in which the ligands were structurally similar to dihydrouracil resulted in the selection of phosphoribosyltransferases, the sequences of which were used in an in silico search in the genome of $M$. incognita for a similar sequence of amino acids. The resulting sequence was modelled and dihydrouracil and $9 H$-purine were inserted in the active site of this putative phosphoribosyltransferase resulting in protein-ligand complexes that underwent molecular dynamics simulations. Calculation of the binding free-energies of these complexes revealed that the dissociation constant of dihydrouracil and $9 H$-purine to this protein is around $8.3 \times 10^{-7}$ and $1.6 \times 10^{-6} \mathrm{M}$, respectively. Consequently, these substances and the putative phosphoribosyltransferase are promising for the development of new products to control M. exigua.
\end{abstract}

Key words: $9 H$-purine, dihydrouracil, molecular modelling, nematicidal activity, root-knot nematode, uracil.

\section{INTRODUCTION}

Plant-parasitic nematodes are a constant source of problems for Brazilian farmers due to the negative impact these animals cause to the production of several crops in Brazil (Dias-Arieira et al. 2010). For example, the production of coffee is severely affected by species of Meloidogyne (Campos and Villain 2005). In the State of Minas Gerais,

Correspondence to: Denilson Ferreira

E-mail:denilson@dqi.ufla.br where $\sim 50 \%$ of this commodity in Brazil is produced (Ministério da Agricultura, Pecuária e Abastecimento - Mapa 2012), Meloidogyne exigua Goeldi occurs in $22 \%$ of the coffee farms in the southern region of this state (Castro et al. 2008). Although exclusion methods and plant resistance to nematodes should be emphasised, synthetic nematicide application is the most often used method to control M. exigua on coffee farms (Campos and Silva 2008), which increases production costs and 
contaminates humans and the environment with harmful substances (Chitwood 2002). A possible alternative to circumvent such problems comprises the use of rhizobacteria, which colonise plant roots and can reduce the population of plant-parasitic nematodes. For example, Pseudomonas fluorescens (Flügge) Migula and Pseudomonas putida Trevisan can reduce the population of Meloidogyne spp. and Radopholus similis (Cobb) Thorne in tomato and banana plants (Aalten et al. 1998). The use of a combination of Bacillus thuringiensis Berliner and Lysinibacillus sphaericus (Meyer and Neide) Ahmed et al. to control plant-parasitic nematodes was protected by a patent (B'Chir 2000).

One of the mechanisms by which rhizobacteria can act against nematodes consists of the production of nematicidal substances, for example the production of 2,4-diacetylphloroglucinol by $P$. Aluorescens that can control Globodera rostochiensis (Wollenweber) Behrens in potato plants (Cronin et al. 1997). Also worthy of mention is the ability of Bacillus amyloliquefaciens (Fukumoto) Priest et al. to produce a cyclic peptide active against nematodes. The use of this substance as a nematicide was protected by a patent some years ago (Bendzko et al. 1998). Thus, in order to select rhizobacteria for the development of new products to control plant-parasitic nematodes and to elucidate their mechanism of action, in a previous work several rhizobacterial strains were screened for the ability to produce substances active against $M$. exigua (Oliveira et al. 2007). Then, the most active crude metabolites underwent a fractionation process monitored by in vitro assays with $M$. exigua second-stage juveniles (J2), which resulted in the identification of common amino acids (Oliveira et al. 2009) that were probably formed in the culture medium by hydrolysis of proteins or peptides that may be used as nutrients by rhizobacteria. Although the low nematicidal properties of amino acids preclude such substances from being commercially used to control $M$. exigua, they are sufficiently active to cause false positive results in a screening program aimed to detect bacterial metabolites with nematicidal activities. Consequently, in a preliminary work they were removed from crude bacterial metabolites by solvent extraction before the screening process. To continue such work, the most active amino-acid-free crude metabolites, produced by Bacillus subtilis Cohn and Bacillus cereus Frankland and Frankland, underwent fractionations in the present study to isolate and identify those substances with nematicidal properties against $M$. exigua. Furthermore, these compounds were also submitted to a computational study to elucidate their mode of action.

\section{MATERIALS AND METHODS}

\section{BACTERIA}

This work was carried out with Bacillus cereus (strain 137JC) and B. subtilis (strain 18JC), which were previously isolated from tomato (Solanum lycopersicum L.), and pepper (Capsicum annum L.) plants, respectively (Silva et al. 2008). Both microorganisms have been deposited in the Department of Plant Pathology-Federal University of Lavras. In order to identify these microorganisms, their DNA was extracted according to the work by Ausubel et al. (1997). Then, the gene coding the ribosomal RNA 16S underwent amplification by polymerase chain reaction (PCR) using the primers fD1 and rP1 (Weisburg et al. 1991). The products of such amplifications were purified by the Qiaquick PCR purification kit (Qiagen) following the manufacture's recommendations. The sequencing reaction was carried out by the chain termination method, using Big Dye 3.1 (Applied Biosystems), followed by analysis in an automated sequencer ABI 377 (Applied Biosystems). The resulting sequences were compared with those deposited in the Ribosomal Database Project, release 10 (http:// rdp.cme.msu.edu) (Cole et al. 2009). 


\section{Production of BaCterial Metabolites}

Each bacterium was grown in $2.5 \mathrm{~L}$ of tryptic soy broth (TSB, Merck) for seven days, at $28^{\circ} \mathrm{C}$, under constant stirring (100 rpm), in the dark. After bacterial cell removal by centrifugation $(10,000 \mathrm{~g}$, $15 \mathrm{~min})$, the supernatant liquids were freeze-dried and washed with dichloromethane $(4 \times 1.0 \mathrm{~L})$. The resulting dichloromethane-soluble fractions were combined and concentrated to dryness in a rotary evaporator to afford the crude extracts. An aliquot $(0.5 \%)$ of each extract was dissolved in $2.0 \mathrm{~mL}$ of an aqueous $0.01 \mathrm{~g} / \mathrm{mL}$ Tween 80 solution to be tested in vitro for activity against $M$. exigua $\mathrm{J} 2$.

\section{IN VITRO ASSAY}

The test was performed as described by Amaral et al. (2002). Briefly, M. exigua eggs were extracted from coffee (Coffea arabica L.) roots infected with the nematode in accordance with the Hussey and Barker (1973) technique, modified by Boneti and Ferraz (1981). J2 were hatched from the eggs and collected to be employed in the in vitro assays. Only less than two-day old J2 were used. Into each $300 \mu \mathrm{L}$ well of a 96-well polypropylene plate, $20 \mu \mathrm{L}$ aqueous suspension containing approximately $25 \mathrm{~J} 2$ and $100 \mu \mathrm{L}$ of samples dissolved in aqueous $0.01 \mathrm{~g} /$ $\mathrm{mL}$ Tween 80 solution, was poured. To evaluate the crude extracts, $30 \mu \mathrm{L}$ of $3.0 \mathrm{mg} / \mathrm{mL}$ Pentabiótico (a mixture of antibacterial substances produced by Fort Dodge, Brazil) suspension was also poured into each well to prevent bacterial growth. After $48 \mathrm{~h}$ at $28^{\circ} \mathrm{C}$, one drop of an aqueous $1.0 \mathrm{M}$ $\mathrm{NaOH}$ solution was added and $\mathrm{J} 2$ which changed their body shape from straight to curled or hookshaped within 3 min were considered to be alive, whereas the nematodes not responding to the addition of $\mathrm{NaOH}$ were considered dead. This experiment was performed with four replicates per treatment, employing aqueous $0.01 \mathrm{~g} / \mathrm{mL}$ Tween 80 solution and aldicarb [(2-methyl-2(methylthio)propanal $O$-( $N$-methylcarbamoyl) oxime] $(50 \mu \mathrm{g} / \mathrm{mL})$ as negative and positive controls, respectively. For the aldicarb solution preparation, $8.6 \mathrm{~g}$ of Temik 150 (150 g of aldicarb/ $\mathrm{kg}$ ), from Rhône-Poulenc AgroBrasil Ltda, was suspended in water and filtered through filter paper. The resulting solution was diluted with water to the desired concentration. All values of dead J2 were converted to percentage before analysis of variance (ANOVA) and means separation according to the Scott and Knott (1974) test $(P \leq 0.05)$, which were performed using the SISVAR 5.1 software (Sistema para Análises Estatísticas, UFLA, Lavras, 2006).

\section{FraCtionATION OF BACTERIAL EXTRACTS}

Dichloromethane-soluble crude extracts, obtained as described above, were successively eluted through a silica gel column $(3 \times 15 \mathrm{~cm} ; 40-63 \mu \mathrm{m}$, Merck) with hexane $(400 \mathrm{~mL})$, hexane/ethyl acetate $(1: 1,400 \mathrm{~mL})$, ethyl acetate $(400 \mathrm{~mL})$, methanol $(800 \mathrm{~mL})$, distilled water $(1600 \mathrm{~mL})$ and $0.1 \mathrm{M}$ hydrochloric acid $(1600 \mathrm{~mL})$. All resulting fractions were concentrated in a rotary evaporator and freeze-dried. The analytical and semi-preparative high performance liquid chromatography (HPLC) analyses and fractionations were carried out on a Shimadzu instrument (Tokyo, Japan) equipped with a photodiode array detector, model SPD-M20A, set at 190-400 nm; pumps LC-6AD; injector Reodyne $7725 \mathrm{i}$ or auto-injector SIL-10AF; degasser DGU $20 \mathrm{~A}_{3}$; and CBM-20A (SCL-10Avp) interface. Data were processed on LC-SOLUTION 1.21 software (Shimadzu). Only those fractions eluted with methanol were submitted to HPLC analyses with a Gemini Si-C18 column (4.6 mm x $250 \mathrm{~mm}$ x $5 \mu \mathrm{m}$, Phenomenex). A gradient elution at a flow rate of $1.0 \mathrm{~mL} / \mathrm{min}$ was carried out employing water $(10$ $\mathrm{min}$ ), water/methanol (0 to $100 \%$ methanol, 10-40 $\mathrm{min}$ ) and methanol (40-50 $\mathrm{min})$, as mobile phases.

The methanol-eluted fraction from $B$. cereus was fractionated on the HPLC system equipped with a semi-preparative Gemini Si-C18 column (21.2 mm x $250 \mathrm{~mm}$ x $5 \mu \mathrm{m}$, Phenomenex), employing water (0-10 $\mathrm{min})$, water/methanol 
(0-100\%, 10-40 $\mathrm{min})$ and methanol (40-50 $\mathrm{min})$ as mobile phases, at a flow rate of $15.0 \mathrm{~mL} / \mathrm{min}$. All eluents contained $0.1 \%(\mathrm{v} / \mathrm{v})$ acetic acid. All fractions were concentrated in a rotary evaporator, freeze-dried and analysed by HPLC. Only fraction 2 (8.5-9.1 min; uracil: $3.3 \mathrm{mg}$ ) was submitted to the identification process.

Similarly, the methanol-eluted fraction of $B$. subtilis underwent fractionation by HPLC to afford seven new fractions, among which those numbered 1 (4.6-8.9 $\mathrm{min})$ and 3 (16.5-19.2 $\mathrm{min})$ were further purified by a new elution through the semipreparative Gemini column with an aqueous $0.1 \%$ $(\mathrm{v} / \mathrm{v})$ acetic acid solution at flow rates of $2.3 \mathrm{~mL} / \mathrm{min}$ and $13.0 \mathrm{~mL} / \mathrm{min}$, respectively. After concentration to dryness in a rotary evaporator and freeze-drying, dihydrouracil (51.4-54.8 $\mathrm{min} ; 19.1 \mathrm{mg}$ ) and uracil (57.1-60.2 $\mathrm{min} ; 1.2 \mathrm{mg}$ ) were obtained as white solids from fraction 1, while fraction 3 afforded 9H-purine (24.2-25.7 $\mathrm{min} ; 3.2 \mathrm{mg}$ ).

\section{IDENTIFICATION OF ISOLATED SUBSTANCES}

To obtain mass spectra, $\sim 0.5 \mathrm{mg}$ of each substance was dissolved in $0.5 \mathrm{~mL}$ water/methanol (1:1) solution and $20 \mu \mathrm{L}$ of the resulting solutions were directly infused at a flow rate of $5.0 \mu \mathrm{L} / \mathrm{min}$ into an Agilent 1100 LC/MS Trap mass spectrometer equipped with an electrospray ionization source in positive and negative ion modes. Probe and cone were maintained at $\pm 3.5 \mathrm{kV}$ and $\pm 25 \mathrm{~V}$, respectively. Nitrogen at $250^{\circ} \mathrm{C}$ was used as nebuliser $(200 \mathrm{~L} / \mathrm{h})$ and gas drier $(20 \mathrm{~L} / \mathrm{h})$, while selected ions underwent fragmentation by collisions with helium at $6 \times 10^{-6}$ bar. Substances were also introduced into a Shimadzu mass spectrometer model PQ5050 through a probe, which was heated from $60^{\circ} \mathrm{C}$ to $300^{\circ} \mathrm{C}$ for $20 \mathrm{~min}$. Ionization was carried out by electron impact at $70 \mathrm{eV}$.

Substances were also dissolved in $0.8 \mathrm{~mL}$ of hexadeuterated dimethyl sulphoxide to obtain hydrogen $\left({ }^{1} \mathrm{H}\right)$ and carbon-13 $\left({ }^{13} \mathrm{C}\right)$ nuclear magnetic resonance (NMR) spectra on a Bruker AVANCE
DPX 200 spectrometer $\left({ }^{1} \mathrm{H}\right.$ at $200 \mathrm{MHz}$ and ${ }^{13} \mathrm{C}$ at $50 \mathrm{MHz}$ ). Solvent peak was used as reference.

CONCENTRATION Lethal TO 50\% OF THE INDIVIDUALS $\left(\mathrm{LC}_{50}\right)$

Solutions of carbofuran (Sigma-Aldrich, 98\%) and dihydrouracil in aqueous $0.01 \mathrm{~g} / \mathrm{mL}$ Tween 80 solution were prepared and used in the in vitro assay with $M$. exigua $\mathrm{J} 2$ as described above, employing the Tween 80 solution as control. The final concentrations inside the wells were 224, 244, 265 and $296 \mu \mathrm{g} / \mathrm{mL}$ for carbofuran, and 171, 192, 213 and $233 \mu \mathrm{g} / \mathrm{mL}$ for dihydrouracil. Average values of dead J2 were converted to a percentage, corrected $\{$ correct value $=100[($ value - control value $) / 100$ control value]\} and submitted to probit analyses on POLO-PC software (LeOra Software 1987).

\section{PROTEIN ModelLing}

Initially, a search for ligands similar to dihydrouracil was carried out using the ReverseScreen3D web service (Kinnings and Jackson 2011). One of the chains of a tetrameric phosphoribosyltransferase [Protein Data Bank (PDB) code: 1A95; Parry et al. 1998], which was the second ranked by ReverseScreen3D, was submitted to a search for genes coding for similar amino acid sequences through the BLAST server available at the $M$. incognita resources web page (http://www.inra.fr/ meloidogyne_incognita/genomic_resources). This search was carried out using TBLASTN 2.2.15 (databases: Minco_dbest_20081106, MiV1_2995. scaf.refandMiV1_unplaced_reads.fas) andBLASTP 2.2.15 (database: MincV1A1.fas) (Altschull et al. 1997). The same search was also carried out for other phosphoribosyltransferases deposited in the Protein Data Bank (http://www.rcsb.org): 1TC2 (Focia et al. 1998), 3OZF (M. Ho et al. unpublished data), 1BZY (Shi et al. 1999), 3 OS4 (N. Maltseva et al. unpublished data), 2EHJ (N.K. Lokanath et al. unpublished data), 3G6W (Christoffersen et al. 2009), 1BD4 (Schumacher et al. 1998), 1ORE (Silva et al. 2004a), 1L1Q (Shi et al. 2002), 1MZV 
(Silva et al. 2004b), 1QB7 (Phillips et al. 1999), 2H3D (Wang et al. 2006a), 1VQU (Joint Center for Structural Genomics, unpublished data) and 3LAR (Kang et al. 2011). The sequences with the highest scores (prot: Minc06801, contig: MiV1ctg193; prot: Minc10020, contig: MiV1ctg367; and prot: Minc03376, contig: MiV1ctg69) obtained when the amino acid sequence of 1BZY was searched against the MincV1A1.fas database, were combined to form the sequence of the putative phosphoribosyltransferase from $M$. incognita (PPTM_A). Then, using the SWISS-MODEL Workplace (Arnold et al. 2006), this sequence was submitted to the SWISS-MODEL automated protein homology-modelling service (Schwede et al. 2003), which used chain A of the homotetramer 1BZY (1BZY_A) as the template. Employing Swiss PDBViewer 4.0.4 (Guex and Peitsch 1997), the generated tridimensional structure was aligned with each one of the four chains of 1BZY to generate a tetramer (PPTM). Multiple sequence alignments of the putative phosphoribosyltransferase from Meloidogyne incognita (PPTM_A), the amino acids sequences of the genome from this nematode (prot: Minc06801, contig: MiV1ctg193; prot: Minc10020, contig: MiV1ctg367; and prot: Minc03376, contig: MiV1ctg69), chain A of 1BZY and another putative phosphoribosyltransferase from $M$. incognita that was described in the literature (0186631, Kloek et al. 2005) were performed using ClustalW 2 (Larkin et al. 2007) in Seaview 4.3.3 software (Gouy et al. 2010) and plotted by Jalview 2.7 software (Waterhouse et al. 2009) (Figure 2).

Optimisation OF THE Protein StruCture ContAining

\section{BACTERIAL METABOLITES}

Initially, both dihydrouracil and $9 H$-purine underwent optimisation with the Hamiltonian RM1, using the software MOPAC 2009 (James J. P. Stewart, Stewart Computational Chemistry, Version $11.052 \mathrm{~W})$. In this step, water was implicitly considered using the conductor-like screening model (COSMO). Four molecules of each optimised structure were aligned with four molecules of the ligand \{phosphoric acid mono-[5-(2-amino-4-oxo4,5-dihydro-3h-pyrrolo[3,2-d]pyrimidin-7-yl)-3,4dihydroxy-pyrrolidin-2-ylmethyl] ester $\}$ that was complexed to 1BZY. Using Swiss PDBViewer 4.0.4 (Guex and Peitsch 1997), each chain of PPTM was aligned with the corresponding chain in 1BZY and merged with the optimised structures, resulting in two complexes containing four molecules of each ligand: PPTM-dihydrouracil and PPTM-9H-purine. The optimised structures of dihydrouracil and $9 \mathrm{H}$-purine were also used for the generation of Charmm topology and parameter files based on the Charmm General Force Field (top_all36_cgenff.rtf and par_all36_cgenff.prm, v. 2a5) by using MATCH software (Yesselman et al. 2012). The PPTM-dihydrouracil and PPTM- $9 H$ purine complexes underwent optimisation of the protein side-chains by SCWRL4 software (Krivov et al. 2009) and hydrogen atoms were added to the protein by the autoPSF plugin of VMD 1.9.1 software (Humphrey et al. 1996), which employed the generated topology files for the ligands and the Charmm topology file top_all27_prot_lipid.rtf for protein. Finally, the resulting complexes were minimised by NAMD 2.8 software (Phillips et al. 2005) using the generated parameter files for the ligands and the Charmm parameter file par_all27_ prot_lipid.prm for protein. Solvent was implicitly considered in this step (Generalized Born), which comprised 1000 iterations.

\section{Molecular Dynamics Simulations}

The minimised protein-ligand complexes were solvated with the Solvate plugin of VMD 1.9.1, to result in rectangular systems in which the minimum distance between protein and sides of the rectangle was $19 \AA$. These were neutralised by the Autoionize plugin of the same software, which added 32 sodium cations $\left(\mathrm{Na}^{+}\right)$to each system. The final systems 
underwent minimisation by NAMD 2.8 with the Charmm force field (5000 iterations), followed by NPT (isothermal-isobaric ensemble) molecular dynamics simulations for $3 \mathrm{~ns}$, at $300 \mathrm{~K}$, employing 2 fs time step, Particle Mesh Ewald (PME) algorithm to take electrostatic interactions into account, constant temperature control by Langevin dynamics, constant pressure dynamics by Nosé-Hoover Langevin piston and periodic boundary conditions. NAMDPlot (a plugin of VMD) was used to extract data from the output files generated by NAMD, while trajectory was analysed employing RMSD Trajectory Tool (another plugin of VMD), which aligned all frames to the starting structure before calculating root-mean square deviation (RMSD).

\section{LiGAND BINDING AFFINITIES}

A frame with the smallest total energy in the last 300 ps of each of the above-mentioned molecular dynamics simulation was taken, and water as well as $\mathrm{Na}^{+}$ions were removed. Both resulting pdb files containing only the protein-ligand complexes were manually altered and finally corrected by Swiss PDBViewer 4.0.4 in order to get them to the appropriate format for calculation of the binding free-energy by the use of PEARLS software (Han et al. 2006).

Using VMD, the last 200 ps of the dcd files generated by NAMD were converted to dcd files containing only protein and ligands, which were transformed into Amber trj trajectory files by the use of Simulaid software (Mezei 2010). The last frame of each simulation was converted by VMD to a pdb file containing only protein and the ligand. Then, the resulting pdb files were transformed into Amber pdb files by Simulaid software, to be used in the generation of Amber prmtop files by Chimera 1.6.1 software (Pettersen et al. 2004), which employed Amber Force Field ff99SB for protein and General Amber Force Field (GAFF; Wang et al. 2004) for ligands. Charges of ligands were computed through the AM1-BCC method, using the Antechamber (Wang et al. 2006b) module of Chimera. Both trj and prmtop files were used by Sietraj-20-03-2012 software (Cui et al. 2008, Naïm et al. 2007) to carry out solvated interaction energy (SIE) calculations in order to obtain the binding free-energies of ligands to protein.

\section{RESULTS AND DISCUSSION}

The phylogenetic analysis of the partial 16S ribosomal DNA sequences revealed that the bacterial isolates corresponded to $B$. cereus and $B$. subtilis, which seems reasonable since species in the genera Bacillus are among the most beneficial rhizobacteria described in the literature (Benizri et al. 2001). B. cereus is widely distributed in nature, being commonly found in soil (Oka et al. 1993), while $B$. subtilis is described as a plant growthpromoting rhizobacteria (Gupta et al. 2000, Ongena et al. 2005).

According to Bunch et al. (2003), amino acids present low solubility in liquids like dichloromethane. Thus, this was the solvent of choice to eliminate these substances, since they could produce false positives during the in vitro assay with $M$. exigua J2 (Oliveira et al. 2009). When submitted to the previously mentioned assay, dichloromethanesoluble metabolites produced by both $B$. cereus and $B$. subtilis presented activity against the nematode (Table I). This result seems reasonable since these bacteria can reduce the population of root-knot nematodes (Meloidogyne spp.) in plant roots (Araújo and Marchesi 2009, Xiao et al. 2012). According to the literature, this activity may be a result of the production of macromolecules active against nematodes by these bacteria (Germida et al. 2000, Sela et al. 1998).

After the fractionation by elution through a silica gel column, both dichloromethane-soluble metabolites afforded six fractions (Table II), amongst which those eluted with methanol presented the largest amounts. Thus, they were used in the following step that comprised HPLC analyses. The other fractions were stored for future work. 
TABLE I

Effect of dichloromethane-soluble metabolites produced by Bacillus cereus and B. subtillis on Meloidogyne exigua second-stage juveniles (J2).

\begin{tabular}{cc}
\hline Dichloromethane-soluble metabolites & Dead J2 (\%) \\
\hline B. cereus at $1.22 \mathrm{mg} / \mathrm{mL}$ & $51 \mathrm{~b}$ \\
B. subtilis at $0.72 \mathrm{mg} / \mathrm{mL}$ & $60 \mathrm{c}$ \\
Tween 80 at $0.01 \mathrm{~g} / \mathrm{mL}$ (negative control) & $6 \mathrm{a}$ \\
Aldicarb at $50 \mu \mathrm{g} / \mathrm{mL}$ (positive control) & $83 \mathrm{~d}$ \\
\hline
\end{tabular}

${ }^{a}$ Means followed by the same letter do not differ significantly $(P \leq 0.05)$.

TABLE II

Fractions of dichloromethane-soluble metabolites produced by Bacillus cereus and B. subtilis, obtained after elution through a silica gel column.

\begin{tabular}{ccc}
\hline Fractions & \multicolumn{2}{c}{ Amount (mg) } \\
& B. cereus & B. subtilis \\
\hline Hexane & 1.5 & 4.6 \\
Hexane/ethyl acetate (50:50) & 1.9 & 7.5 \\
Ethyl acetate & - & 10.1 \\
Methanol & 108.0 & 129.0 \\
Water & - & - \\
0.1 M hydrochloric acid & - & - \\
\hline
\end{tabular}

"-" Less than $0.1 \mathrm{mg}$.

The methanol fractions (Table II) were still very complex according to HPLC analyses. Thus, during the semi-preparative HPLC process, the main goal was the purification of substances present in larger amounts that could not be detected in the dichloromethane-soluble fraction of TSB not exposed to the bacteria. Such a process resulted in four fractions that underwent NMR and mass spectrometry analyses to elucidate their chemical structures. Interpretation and comparison of data with those reported in the literature allowed the identification of three substances: uracil, dihydrouracil and 9H-purine (Figure 1). The metabolite produced by $B$. cereus that was purified and identified was identical to one of the substances obtained from B. subtilis (see Experimental procedures: Fractionation of bacterial metabolites).

Chemical shifts observed (Table III) during the NMR analyses are in perfect agreement with NMR data published for dihydrouracil (Roberts
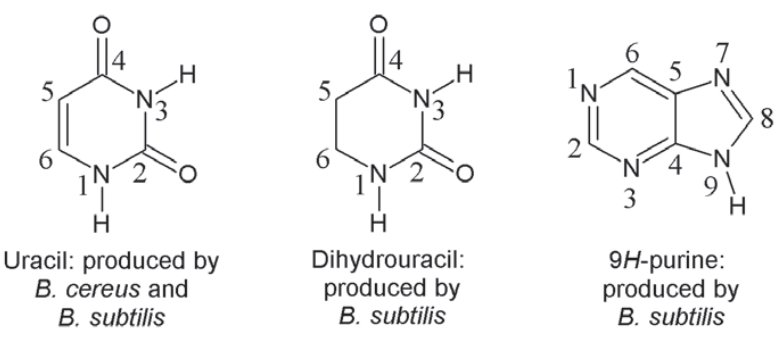

Figure 1 - Metabolites produced by Bacillus cereus and B. subtilis.

and Poulter 1978), uracil (Roberts and Poulter 1978) and 9H-purine (Therese et al. 1975). Such results were corroborated by the mass spectrometry analyses, since $9 \mathrm{H}$-purine afforded peaks at $\mathrm{m} / \mathrm{z}$ (mass-to-charge ratio) $121[\mathrm{M}+\mathrm{H}]^{+}$and $119[\mathrm{M}-\mathrm{H}]^{+}$ during the positive and negative ion mode analyses, respectively, performed by direct infusion of the substance into the electrospray ionization source. Regarding dihydrouracil and uracil, peaks at $\mathrm{m} / \mathrm{z}$ $114\left(\mathrm{M}^{+}\right)$and $112\left(\mathrm{M}^{+*}\right)$ were respectively obtained after the electron impact ionization process.

When tested for in vitro activity against $M$. exigua $\mathrm{J} 2$, all the isolated substances significantly increased nematode mortality (Table IV). For dihydrouracil, which was the most active structure, a $\mathrm{LC}_{50}$ of $204 \mu \mathrm{g} / \mathrm{mL}$ was obtained while the commercial nematicide carbofuran (2,2-dimethyl2,3-dihydro-1-benzofuran-7-yl methylcarbamate) presented a $\mathrm{LC}_{50}$ of $260 \mu \mathrm{g} / \mathrm{mL}$ under the same conditions, suggesting that dihydrouracil could be a more efficient nematicide than carbofuran. Although various biological properties have already been described for dihydrouracil (Roberts and Poulter 1978), uracil (Roberts and Poulter 1978) and 9H-purine (Therese et al. 1975), this is the first time that their nematicidal properties have been demonstrated. Thus, in order to understand their mode of action, an in silico study was carried out to identify the nematode enzyme that these substances may be affecting.

This part of the work initiated with a search for protein-ligand systems in which the ligand was 
TABLE III

Hydrogen $\left({ }^{1} \mathrm{H}\right)$ and carbon-13 $\left({ }^{13} \mathrm{C}\right)$ chemical shifts (ppm), number of hydrogens (H), multiplicity (d: doublet; s: singlet; t: triplet; dt: double triplet; br s: broad singlet) and coupling constant $(\mathrm{J})$ in $\mathrm{Hz}$, obtained by nuclear magnetic resonance analyses of dihydrouracil, uracil and $9 \mathrm{H}$-purine.

\begin{tabular}{ccccccc}
\hline Position $^{\mathbf{a}}$ & \multicolumn{2}{c}{ Uracil } & \multicolumn{2}{c}{ Dihydrouracil } & \multicolumn{2}{c}{$\mathbf{9 H}$-purine } \\
& ${ }^{13} \mathbf{C}$ & ${ }^{1} \mathbf{H}$ & ${ }^{13} \mathbf{C}$ & ${ }^{1} \mathbf{H}$ & ${ }^{13} \mathbf{C}$ & ${ }^{1} \mathbf{H}$ \\
\hline 1 & - & - & - & $7.39 \mathrm{NH}$ br s & - & - \\
2 & 151.5 & - & 154.0 & - & 151.9 & $9.061 \mathrm{H} \mathrm{s}$ \\
3 & - & - & - & $9.84 \mathrm{NH}$ br s & - & - \\
4 & 164.3 & - & 171.1 & - & 154.8 & - \\
5 & 100.2 & $5.451 \mathrm{H}$ d J 7.6 & 30.4 & 2.35 2H t J 6.7 & 130.5 & - \\
6 & 142.2 & $7.401 \mathrm{H} \mathrm{d} \mathrm{J} \mathrm{7.6}$ & 35.4 & $3.12 \mathrm{H} \mathrm{dt} \mathrm{J} \mathrm{2.4/6.7}$ & 145.4 & 9.11 1H s \\
7 & - & - & - & - & - & - \\
8 & - & - & - & - & 146.4 & $8.591 \mathrm{H} \mathrm{s}$ \\
9 & - & - & - & - & - & - \\
\hline
\end{tabular}

${ }^{\text {a }}$ See Figure 1.

"-" Without absorption.

TABLE IV

Effect of isolated bacterial metabolites at $500 \mu \mathrm{g} / \mathrm{mL}$ on Meloidogyne exigua second-stage juveniles (J2).

\begin{tabular}{cc}
\hline Substance & Dead J2 (\%) $)^{\mathrm{a}}$ \\
\hline Dihydrouracil & $100 \mathrm{~d}$ \\
Uracil & $38 \mathrm{c}$ \\
$9 H$-purine & $21 \mathrm{~b}$ \\
Tween $80(0.01 \mathrm{~g} / \mathrm{mL})$ & $2 \mathrm{a}$ \\
\hline
\end{tabular}

${ }^{a}$ Means followed by different letters differ significantly $(P \leq 0.05)$.

structurally similar or identical to dihydrouracil. The best-matched system, with a 3Dscore of 0.80 (Kinnings and Jackson 2011), comprised an enzyme for telomere protection. As no relation with nematodes for this protein could be found in the literature, it was discarded. The next system in the rank (3Dscore $=0.72$ ) consisted of a phosphoribosyltransferase complexed to xanthine (PDB code: 1A95; Parry et al. 1998), which was interesting since most parasites are unable to synthesise purine bases by de novo pathways. Thus, enzymes in the salvage pathways of preformed bases, like the phosphoribosyltransferases, are potential targets for the development of new products to control parasites (Craig III and Eakin 2000), especially those of the Meloidogyne genus
(Kloek et al. 2005, Liu et al. 2006). Consequently, a search for analogous sequences of amino acids produced by $M$. exigua was carried out, but no good match could be found. Since the genomic information about Meloidogyne incognita (Kofoid and White) Chitwood is more comprehensive, it was used instead of $M$. exigua, resulting in some sequences that could correspond to a phosphoribosyltransferase. However, the scores for these sequences were very low (28 bits; Altschull et al. 1997). Therefore, the sequences of other phosphoribosyltransferases deposited in the Protein Data Bank (http://www.rcsb.org) were also used in this search and the best result was obtained for the PDB code 1BZY (Shi et al. 1999), which is a human homotetrameric enzyme. Scores of 143, 142 and 140 bits were obtained for the Minc06801 (contig: MiV1ctg193), Minc10020 (contig: MiV1ctg367) and Minc03376 (contig: MiV1ctg69) amino acids sequences, respectively, when the search was carried out in the MincV1A1.fas database. As these sequences were very similar to each other, they were combined to form the sequence of the putative phosphoribosyltransferase from $M$. incongita (PPTM_A; Figure 2). The score of the alignment 
of PPTM_A with 1BZY was 36.0\%, while for another putative phosphoribosyltransferase from M. incognita (0186631, Kloek et al. 2005) the scores of the alignments with PPTM_A and 1BZY were 8.0 and $10.0 \%$, respectively, suggesting the production by $M$. incognita of enzymes with similar functions, but with large differences in their amino acid sequences.

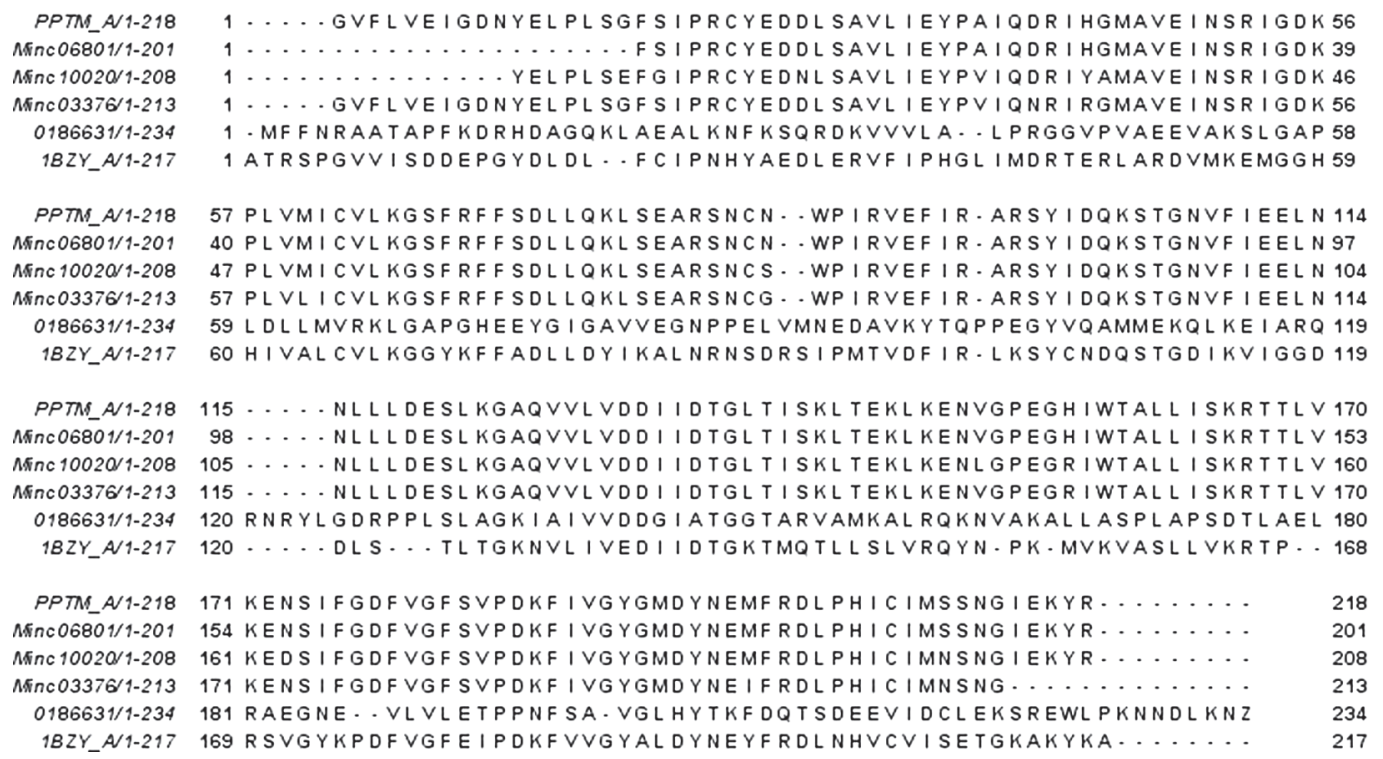

Figure 2 - Amino acid sequences from: the putative phosphoribosiltransferase from Meloidogyne incognita (PPTM_A); the genome from this nematode (prot: Minc06801, contig: MiV1ctg193; prot: Minc10020, contig: MiV1ctg367; and prot: Minc03376, contig: MiV1ctg69); chain A of 1BZY (1BZY_A), which is a human enzyme of the same class; and another putative phosphoribosyltransferase from $M$. incognita that was described in the literature (0186631, Kloek et al. 2005). Sequences were aligned by ClustalW 2 (Larkin et al. 2007) in SeaView 4.3.3 software (Gouy et al. 2010) and ploted by Jalview 2.7 software (Waterhouse et al. 2009).

In the following step, PPTM_A underwent homology modelling, which was carried out using chain A of 1BZY (1BZY_A) as the template. This process resulted in a three-dimensional structure (PPTM) with a Z-score of -2.217 according to the Qmean4 global score (SWISS-MODEL Workplace; Benkert et al. 2011). As 1BZY is a tetramer, four chains of PPTM were used to build the complete protein complexed to the bacterial metabolites. In this study, only dihydrouracil and $9 \mathrm{H}$-purine were used. To reduce any clashes or torsion problems in the protein structure, the complexes PPTM-dihydrouracil and PPTM$9 \mathrm{H}$-purine had the positions of their side chains corrected and both systems were minimised before the molecular dynamics simulation process, which was carried out until stabilisation of their RMSD (Figure 3).

Frames with the lowest total energy in the last 300 ps of each simulation (Figure 4) were used for the free-energy calculation with PEARLS (Han et al. 2006), which is a force-field-based scoring function. The calculated binding freeenergy for dihydrouracil (Table $\mathrm{V}$ ) corresponded to a dissociation constant $\left(K_{\mathrm{d}}\right)$ of $\sim 1.3 \times 10^{-5} \mathrm{M}[\mathrm{ln}$ $\left(1 / K_{\mathrm{d}}\right)=-\Delta \mathrm{G}^{\mathrm{o}} / 2476.38$; where $\Delta \mathrm{G}^{\mathrm{o}}$ : binding Gibbs free-energy, in Joules], while the $K_{\mathrm{d}}$ for $9 H$-purine was $3.5 \times 10^{-5} \mathrm{M}$, which is in accordance with the greater in vitro nematicidal activity of dihydrouracil (Table IV). 


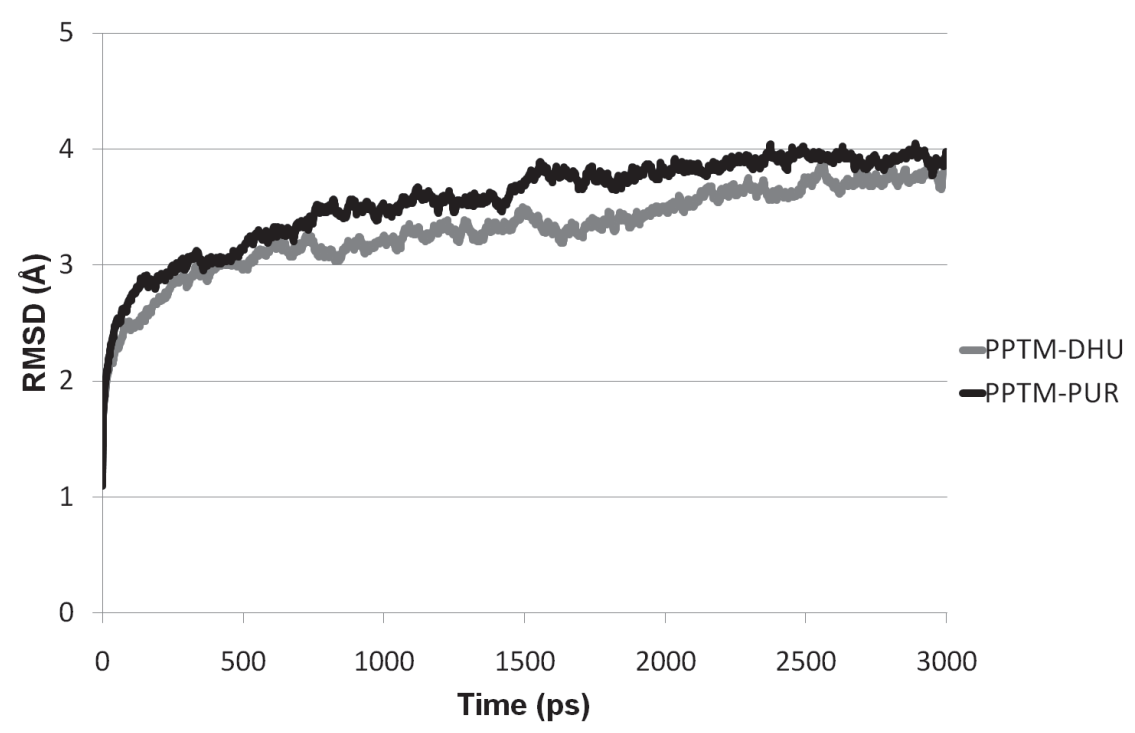

Figure 3 - Root mean square deviation (RMSD) of the putative phosphoribosyltransferase from Meloidogyne incognita, during the molecular dynamics simulation of the complex of this enzyme with dihydrouracil (PPTM-DHU) and 9H-purine (PPTM-PUR).
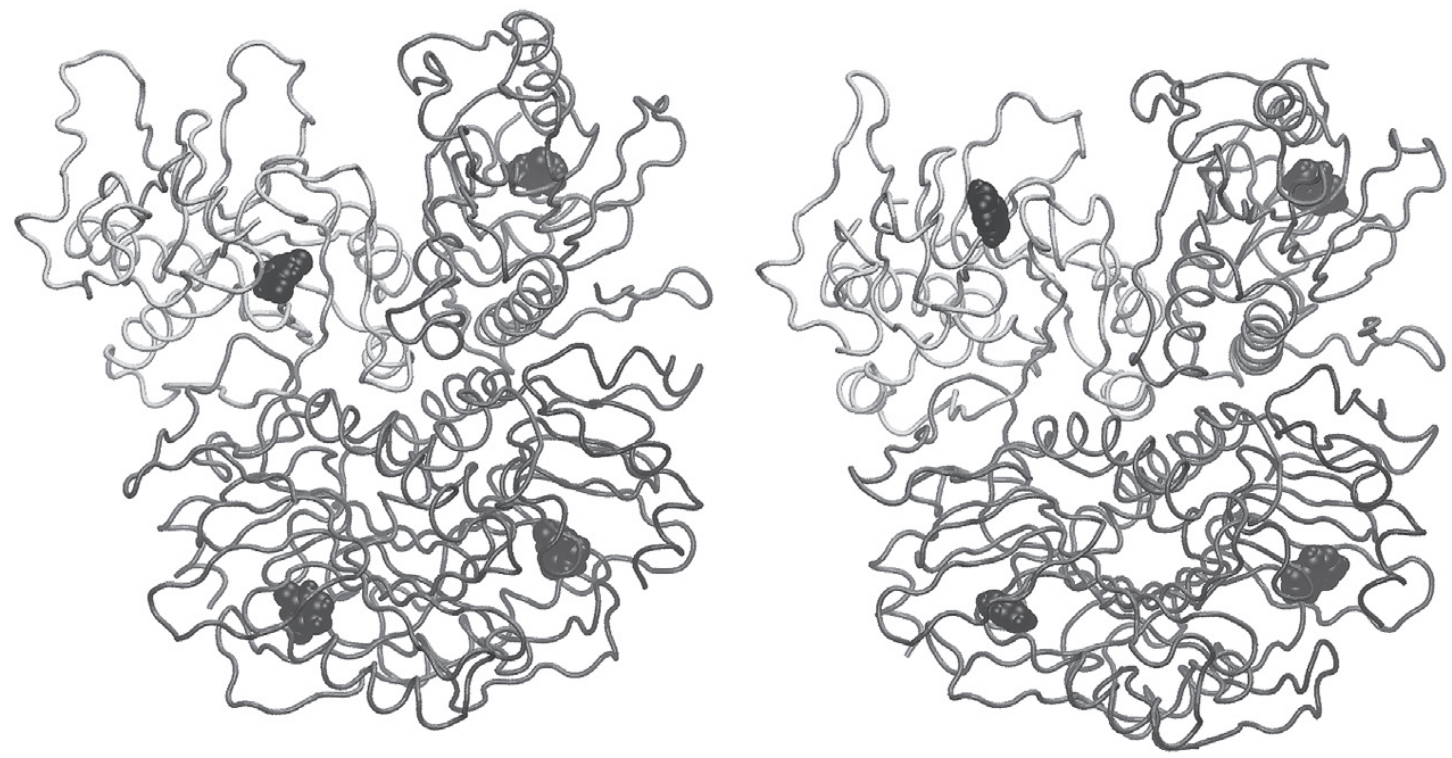

Figure 4 - Structures of the complexes PPTM-dihydrouracil (right side) and PPTM-9H-purine (left side), in which the protein is represented by Tube format and ligands are represented by the VDW format. This image was created by VMD 1.9.1 software.

In an attempt to obtain more reliable values for the binding affinities of dihydrouracil and $9 H$-purine to PPTM, each snapshot of the last 200 ps of the molecular dynamics simulation of the complexes PPTM-dihydrouracil and PPTM$9 H$-purine underwent calculation of SIE by rigid infinite separation of the protein and ligands. SIE was the sum of the intermolecular van der Waals and Coulomb interactions plus the change in reaction field energy and nonpolar solvation energy. Entropy was considered by scaling values with an empirically determined factor that was 
TABLE V

Binding affinities of dihydrouracil and $\mathbf{9 H}$-purine to the putative phosphoribosyltransferase (PPTM) from Meloidogyne incognita.

\begin{tabular}{ccc}
\hline \multirow{2}{*}{ Method } & \multicolumn{2}{c}{ Binding affinity $(\mathbf{k c a l} / \mathbf{m o l})$} \\
\cline { 2 - 3 } & Dihydrouracil & $\mathbf{9 H}$-purine \\
\hline PEARLS $^{\mathrm{a}}$ & -6.64 & -6.08 \\
Sietraj $^{\mathrm{b}}$ & $-8.29 \pm 0.59$ & $-8.01 \pm 0.56$ \\
\hline
\end{tabular}

${ }^{a}$ Values correspond to the average of the binding free-energy of the four ligand molecules, in the frame with the smaller energy in the last 300 ps of the molecular dynamics simulation trajectory.

${ }^{b}$ Values correspond to the average of the binding free-energy of the four ligand molecules plus the standard deviation, in all frames of the last $200 \mathrm{ps}$ of the molecular dynamics simulation trajectory.

obtained by the authors of the software employed in this calculation (Cui et al. 2008, Naïm et al. 2007). The binding free-energy of dihydrouracil to PPTM (Sietraj, Table V) corresponded to a $K_{\mathrm{d}}$ of $\sim 8.3 \times 10^{-7} \mathrm{M}$, which suggests that this substance is a better inhibitor of PPTM than $9 H$-purine, for which the $K_{\mathrm{d}}$ was $\sim 1.6 \times 10^{-6} \mathrm{M}$.

In summary, this study has demonstrated that uracil produced in vitro by $B$. cereus and B. subtilis, as well as dihydrouracil and $9 H$-purine produced by the latter rhyzobacterium, were active against $M$. exigua J2. Specifically for dihydrouracil, the $\mathrm{LC}_{50}$ against $M$. exigua was less than that observed for the commercial nematicide carbofuran, suggesting that dihydrouracil is a promising substance for the control of plant-parasitic nematodes. According to the in silico study, these substances may be acting against $M$. exigua through inhibition of its phosphoribosyltransferase, which maybe a promising enzyme for the development of new products to control Meloidogyne spp., since this macromolecule appears to be important for the salvage pathways of preformed bases in these pathogens.

\section{ACKNOWLEDGMENTS}

The authors express their sincere thanks to Dr. José Dias de Souza Filho and Dr. Ivana Silva Lula (Departamento de Química, Universidade Federal de Minas Gerais - UFMG, Brazil) for providing access to nuclear magnetic resonance facilities and Dr. Flaviano Oliveira Silvério for mass spectrometry spectra (Departamento de Química, Universidade Federal de Viçosa - UFV, Brazil). The authors also gratefully acknowledge: Coordenação de Aperfeiçoamento de Pessoal de Nível Superior (CAPES), Conselho Nacional de Desenvolvimento Científico e Tecnológico (CNPq) and Fundação de Amparo à Pesquisa do Estado de Minas Gerais (FAPEMIG) for financial support and fellowships; Centro Nacional de Supercomputação (CESUP) at the Universidade Federal do Rio Grande do Sul (UFRGS), where part of the present work was developed; the Theoretical and Computational Biophysics Group in the Beckman Institute for Advanced Science and Technology at the University of Illinois at Urbana-Champaign, who developed NAMD and VMD; and the developers of Chimera: Resource for Biocomputing, Visualization, and Informatics at the University of California, San Francisco, with support from the National Institutes of Health (National Center for Research Resources grant 2P41RR001081, National Institute of General Medical Sciences grant 9P41GM103311).

\section{RESUMO}

Com o objetivo de contribuir para o desenvolvimento de produtos para o controle de Meloidogyne exigua, as bactérias Bacillus cereus e B. subtilis foram cultivadas em meio líquido de cultura para produzirem metabólitos ativos contra este nematoide parasita de plantas. Os fracionamentos dos extratos em diclorometano dos meios de cultura produziram uracila, $9 H$-purina e di-idrouracila. Todos os compostos foram ativos contra M. exigua, sendo o último o mais eficiente. Ele apresentou $\mathrm{CL}_{50}$ de 204 $\mu \mathrm{g} / \mathrm{mL}$ contra o nematoide, enquanto uma $\mathrm{CL}_{50}$ de $260 \mu \mathrm{g} / \mathrm{mL}$ foi observada para o nematicida comercial carbofuran. Uma busca por complexos proteínaligante nos quais o ligante fosse estruturalmente similar à di-idrouracila resultou na seleção de fosforibosiltransferases, cujas sequências foram 
utilizadas em uma busca in silico no genoma de $M$. incognita por sequência de aminoácidos semelhante. A sequência resultante foi modelada e di-idrouracila e $9 H$-purina foram inseridos nos sítios ativos desta provável fosforibosiltransferase, resultando em complexos proteína-ligante que foram submetidos a simulações por dinâmica molecular. Cálculos das energias livres de ligação destes complexos revelaram que a constante de dissociação de di-idrouracila e $9 H$-purina da enzima é da ordem de $8,3 \times 10^{-7}$ e $1,6 \times 10^{-6} \mathrm{M}$, respectivamente. Consequentemente, estas substâncias e a provável fosforibosiltransferase podem ser de grande utilidade para o desenvolvimento de novos produtos para o controle de $M$. exigua.

Palavras-chave: $9 H$-purina, di-idrouracila, modelagem molecular, atividade nematicida, nematoide das galhas, uracila.

\section{REFERENCES}

Aalten PM, Vitour D, Blanvillain D, Gowen SR AND SUTRA L. 1998. Effect of rhizosphere fluorescent Pseudomonas strains on plant-parasitic nematodes Radopholus similis and Meloidogyne spp. Lett Appl Microbiol 27: 357-361.

Altschull SF, MADDEN TL, SCHÄFFER AA, ZHANG J, ZHANG Z, MILLER W AND LIPMAN DJ. 1997. Gapped BLAST and PSI-BLAST: a new generation of protein database search programs. Nucleic Acids Res 25: 3389-3402.

AMARAL DR, OLIVEIRA DF, CAMPOS VP AND CARVALHO DA. 2002. Efeito de alguns extratos vegetais na mobilidade, mortalidade e patogenicidade de Meloidogyne exigua do cafeeiro. Nematologia Brasileira 26: 43-48.

ARAúJO FF AND MARChESI GVP. 2009. Uso de Bacillus subtilis no controle da meloidoginose e na promoção do crescimento do tomateiro. Cienc Rural 39: 1558-1561.

Arnold K, Bordoli L, Kopp J And Schwede T. 2006. The Swiss-Model Workspace: A web-based environment for protein structure homology modeling. Bioinformatics 22: 195-201.

Ausubel FM, Brent R, Kingston RE, Moore DD, SEIDMAN JG, SMITH JA AND STRUHL K. 1997. Phenol/SDS method for plant RNA preparation. In: AUSUBEL ET AL. (Eds), Short protocols in molecular biology: a compendium of methods from current protocols in molecular biology. New York: J Wiley \& Sons, p. 4-7.

B'CHIR MM. 2000. Bionematicide with efficient ovicide activity against plant-parasitic nematodes. Patent EP0981277A1, 01 March 2000.
Bendzko P, Etzel W, Hoeding B, Krebs B, Maximov J AND OCKARDT A. 1998. Cyclic peptide(s) from Bacillus amyloliquefaciens - useful as antimycotics, antivirals, fungicides, nematocides, etc. US Patent DE19641213-A1, 16 April 1998.

Benizri E, BAudoin E AND GUCKert A. 2001. Root colonization by inoculated plant growth-promoting rhizobacteria. Biocontrol Sci Technol 11: 557-574.

BENKERT P, BIASINI M AND SChwedE T. 2011. Toward the estimation of the absolute quality of individual protein structure models. Bioinformatics 27: 343-350.

BONETI JIS AND FERRAZ S. 1981. Modificação do método de Hussey e Barker para extração de ovos de Meloidogyne exigua de raízes de cafeeiro. Fitopatol Bras 6: 553.

Bunch ASR, MEUnier D, Rodierb ClC, RAUlina F AND VIDAL-MADJARC C. 2003. Extraction of organic molecules of exobiological interest for in situ analysis of the Martian soil. J Chromatogr A 99: 165-174.

CAMPOS VP AND SILVA JRC. 2008. Management of Meloidogyne spp. in coffee plantations. In: SOUZA RM (Ed), Plant parasitic nematodes of coffee, São Paulo: Springer, p. 149-164.

CAMPOS VP AND VILLAIN L. 2005. Nematode parasites of coffee and cocoa. In: LUC M et al. (Eds), Plant parasitic nematodes in subtropical and tropical agriculture, Wallingford UK: CAB Internacional, p. 529-579.

Castro JMC, CAmpos VP, Pozza EA, Naves RL, ANdRAdE JÚNIOR WC, DUTRA MR, COIMBRA JL, MAXIMINIANO C AND SILVA JRC. 2008. Levantamento de fitonematóides em cafezais do sul de Minas Gerais. Nematologia Brasileira 32: $56-64$.

Chitwood DJ. 2002. Phytochemical based strategies for nematode control. Annu Rev Phytopathol 40: 221-249.

ChristofFERSEN S, KADZIOLA A, JOHANSSON E, RASMUSSEN M, Willemoes M AND JENSEN KF. 2009. Structural and kinetic studies of the allosteric transition in Sulfolobus solfataricus uracil phosphoribosyltransferase: Permanent activation by engineering of the C-Terminus. J Mol Biol 393: 464-477.

COLE JR ET AL. 2009. The ribosomal database project: Improved alignments and new tools for rRNA analysis. Nucleic Acids Res 37: 141-145.

CRAIG III SP AND EAKIN EA. 2000. Purine Phosphoribosyltransferases. J Biol Chem 275: 20231-20234.

CRONIN D, MoËNNE-LocCOZ Y, FenTON A, DUNNE C, DOWLING DN AND O'GARA F. 1997. Role of 2,4-diacetylphloroglucinol in the interactions of the biocontrol pseudomonad strain F113 with the potato cyst nematode Globodera rostochiensis. Appl Environ Microb 63: 1357-1361.

Cui Q, Sulea T, Schrag JD, Munger C, Hung M-N, NaÏM M, CYGler M AND PURISIMA EO. 2008. Molecular dynamics and solvated interaction energy studies of protein-protein interactions: the MP1-p14 scaffolding complex. J Mol Biol 379: 787-802.

Dias-Arieira CR, FurlanetTo C, SANTANa SM, Barizão DAO AND RIBEIRO RCF. 2010. Fitonematoides associados a frutíferas na região noroeste do Paraná, Brasil. Rev Bras Frutic 32: 1064-1071. 
FOCIA PJ, CRAIG III SP AND EAKIN AE. 1998. Approaching the transition state in the crystal structure of a phosphoribosyltransferase. Biochemistry 37: 17120-17127.

Germida JJ, HeIns SD, MANKER DC, JiMENEZ DR AND MARRONE PG. 2000. Bacillus subtilis strain for controlling insect and nematode pests. US Patent 6015553, 01 January 2000.

GouY M, GuINDON S AND GASCUEL O. 2010. SeaView version 4: A multiplatform graphical user interface for sequence alignment and phylogenetic tree building. Mol Biol Evol 27: 221-224.

GuEX N AND PEITSCH MC. 1997. SWISS-MODEL and the Swiss-PdbViewer: An environment for comparative protein modeling. Electrophoresis 18: 2714-2723.

Gupta VP, Bochow H, DoleJ S AND Fischer I. 2000. Plant growth promoting Bacillus subtilis strain as potential inducer of systemic resistance in tomato against Fusarium wilt. Zeitschrift für Pflanzenkrankheiten und Pflanzenschutz 107: 145-154.

HAN LY, LIN HH, Li ZR, ZHENG CJ, CAO ZW, XIE B AND CHEN YZ. 2006. PEARLS: program for energetic analysis of receptor-ligand system. J Chem Inf Model 46: 445-450.

Humphrey W, DALKe A AND SCHULTEN K. 1996. VMD -Visual Molecular Dynamics. J Mol Graphics 14: 33-38.

HUSSEY RS AND BARKER KR. 1973. A compararison of methods of collecting inocula of Meloidogyne spp., including a new technique. Plant Dis Reporter 57: 1025-1028.

Kang GB, Kim MK, Youn HS, AN JY, LeE JG, PARK KR, LEE SH, KIM Y, FUKUOKA SI AND EOM SH. 2011. Crystallization and preliminary X-ray crystallographic analysis of human quinolinate phosphoribosyltransferase. Acta Cryst 67: 38-40.

KINNINGS SL AND JACKSON RM. 2011. ReverseScreen3D: A structure-based ligand matching method to identify protein targets. J Chem Inf Model 28: 624-634.

Kloek AP, Williams DJ AND Salmon B. 2005. Nematode PPPT-like sequences. US Patent 2005/0186631 A1, 25 August 2005.

KRIVOV GG, SHAPOVALOV MV AND DUNBRACK JR RL. 2009. Improved prediction of protein side-chain conformations with SCWRL4. Proteins: Structure, Function and Bioinformatics 77: 778-795.

LARKIN MA ET AL. 2007. ClustalW and ClustalX version 2. Bioinformatics 23: 2947-2948.

LeOra Software. 1987. Polo PC: a user's guide to probit or logit analysis. LeOra Software Inc., Berkely, CA.

Liu L, Burnam L, SLuder A, LinK E AND Westland B. 2006. Screens and assays for agents useful in controlling parasitic nematodes. US Patent 7,064,243 B2, 20 June 2006.

MEZEI M. 2010. Simulaid: a simulation facilitator and analysis program. J Comp Chem 31: 2658-2668.

MAPA - Ministério DA Agricultura, PECuÁria E ABASTECIMENTO. 2012. Informe estatístico do café. 2012. Retrieved June 13, 2012, from http://www.agricultura. gov.br/vegetal/estatisticas
NAÏM M ET AL. 2007. Solvated interaction energy (SIE) for scoring protein-ligand binding affinities. 1. Exploring the parameter space. J Chem Inf Model 47: 122-133.

OKA Y, CHET I AND SPIEGEL Y. 1993. Control of the root-knot nematode Meloidogyne javanica by Bacillus cereus. Biocontrol Sci Technol 3: 115-126.

Oliveira DF, CAMpos VP, AMARAL DR, Nunes AS, PANTALEÃO JA AND COSTA DA. 2007. Selection of rhizobacteria able to produce metabolites active against Meloidogyne exigua. Eur J Plant Pathol 119: 477-479.

Oliveira DF, CARVAlho HWP, Nunes AS, Silva GH, CAmpos VP, JÚNIOR HMS ANd CAVAlheiro AJ. 2009. The activity of amino acids produced by Paenibacillus macerans and from commercial sources against the rootknot nematode Meloidogyne exigua. Eur J Plant Pathol 124: 57-63.

Ongena M, Duby F, Jourdan E, BeAudry T, JAdin V, DOMMES J AND THONART P. 2005. Bacillus subtilis M4 decreases plant susceptibility towards fungal pathogens by increasing host resistance associated with differential gene expression. Applied Microbiol Biotechnol 67: 692-698.

PARRY RJ, Vos S, Burns MR, De Jersey J AND MARTIN JL. 1998. Structures of free and complexed forms of Escherichia coli xanthine-guanine phosphoribosyltransferase. J Mol Biol 282: 875-889.

Pettersen EF, Goddard TD, Huang CC, Couch GS, GreEnBlatt DM, MENG EC AND FERrIN TE. 2004. UCSF Chimera: a visualization system for exploratory research and analysis. J Comput Chem 25: 1605-1612.

Phillips CL, Ullman B, BrenNan RG AND Hill CP. 1999. Crystal structures of adenine phosphoribosyltransferase from Leishmania donovani. Embo J 18, 3533-3545.

PhILlips JC, BRAUn R, WANG W, GUMBART J, TAJKHORSHID E, Villa E, Chipot C, SKeEl RD, Kale L and SChUlten K. 2005. Scalable molecular dynamics with NAMD. J Comput Chem 26: 1781-1802.

Roberts JL AND POUlter CD. 1978. 2',3',5'-Tri-Obenzoyl[413C]uridine. An efficient, regiospecific synthesis of the pyrimidine ring. J Org Chem 43: 1547-1550.

SCHUMACHER MA, CARTER D, SCOTT DM, RoOS DS, ULLMAN B AND BRENNAN RG. 1998. Crystal structures of toxoplasma gondii uracil phosphoribosyltransferase reveal the atomic basis of pyrimidine discrimination and prodrug binding. Embo J 17: 3219-3232.

Schwede T, Kopp J, GUEX N AND PEITSCH MC. 2003. SWISSMODEL: An automated protein homology-modeling server. Nulceic Acids Res 31: 3381-3385.

SCOTT AJ AND KNOTT M. 1974. Cluster analysis method for grouping means in the analysis of variance. Biometrics 30: 507-512.

Sela S, Schickler H, Chet I AND SPIEGEL Y. 1998. Purification and characterization of a Bacillus cereus collagenolytic/proteolytic enzyme and its effect on Meloidogyne javanica cuticular proteins. Eur J Plant Pathol 104: 59-67. 
Shi W, Li CM, Tyler PC, Furneaux RH, GRUBMeyer C, SCHRAMM VL AND ALMO SC. 1999. The $2.0 \AA$ structure of human hypoxanthine-guanine phosphoribosyltransferase in complex with a transition-state analog inhibitor. Nat Struct Biol 6: 588-593.

Shi W, Sarver AE, Wang CC, TANAKa KS, Almo SC AND SCHRAMM VL. 2002. Closed site complexes of adenine phosphoribosyltransferase from Giardia lamblia reveal a mechanism of ribosyl migration. J Biol Chem 277: 39981 39988.

Silva JRC, Souza RM, ZaCARONE AB, Silva LHCP AND CASTRO ANS. 2008. Bactérias endofíticas no controle e inibição in vitro de Pseudomonas syringae pv. tomato, agente da pinta bacteriana do tomateiro. Cienc Agrotec 32: 1062-1072.

Silva M, Silva CHTP, IUlek J, Oliva G and ThiemanN OH. 2004b. Crystal structure of adenine phosphoribosyltransferase from Leishmania tarentolae: Potential implications for aprt catalytic mechanism. Biochem Biophys Acta 1696: 33-39.

Silva M, Silva CHTP, IUleK J AND ThiemanN OH. 2004a. Three-dimensional structure of human adenine phosphoribosyltransferase and its relation to DHAurolithiasis. Biochemistry 43: 7663-7671.

Therese M, PugMire CRJ, Grant DM, PANZICA RP AND TOWNSEND LB. 1975. Carbon-13 magnetic resonance. Quantitative determination of the tautomeric populations of certain purines. J Am Chem Soc 97: 4636-4642.
Wang J, Wang W, Kollman PA And CASE DA. 2006b. Automatic atom type and bond type perception in molecular mechanical calculations. J Mol Graph Model 25: 247-260.

Wang J, Wolf RM, CAldwell JW, Kollman PA AND CASE DA. 2004. Development and testing of a general AMBER force field. J Comput Chem 25: 1157-1174.

WANG T, ZHANG X, BHEDA P, REVOllo JR, IMAI SI AND WOLBERGER C. 2006a. Structure of Nampt/PBEF/visfatin, a mammalian $\mathrm{NAD}(+)$ biosynthetic enzyme. Nat Struct Mol Biol 13: 661- 662.

WATERHOUSE AM, PROCTER JB, MARTIN DMA, CLAMP MAND BARTON GJ. 2009. Jalview Version 2 - a multiple sequence alignment editor and analysis workbench. Bioinformatics 25: 1189-1191.

Weisburg WG, Barns SM, Pelletier DA And Lane DJ. 1991. 16S Ribosomal DNA amplification for phylogenetic study. J Bacteriol 173: 697-703.

XiaO T, TAN S, SHEN Q AND RAN W. 2012. Bacillus cereus X5 suppresses root-knot nematode of tomato by colonizing in roots and soil. Afr J Microbiol Res 6: 2321-2327.

Yesselman JD, Price DJ, KNIGHT JL AND BroOKs III CL. 2012. MATCH: An atom-typing toolset for molecular mechanics force fields. J Comput Chem 33: 189-202. 